\title{
Model Penguatan Pendidikan Karakter Berbasis Kepramukaan Bagi Peserta Didik Berkebutuhan Khusus di Madrasah Ibtidaiyah Al-Hidayah Margorejo Surabaya
}

\author{
Uswatun Chasanah \\ uswatunchasanah@uinsby.ac.id \\ UIN Sunan Ampel Surabaya \\ Majidatun Ahmala \\ STAI Taruna Surabaya \\ mazida23@gmail.com \\ Moh. Isbir \\ STIT Miftahul Ulum Bangkalan \\ ebitjamil@yahoo.co.id
}

\begin{abstract}
Abstrak
Madrasah Ibtidaiyah Al-Hidayah Margorejo Surabaya salah satu madrasah yang sedang menuju madrasah inklusi. Peserta didik di madrasah ini terdiri dari beberapa jenis kategori peserta didik berkebutuhan khusus yaitu; kesulitan belajar, low vision, tuna daksa dan speech delay. Peserta didik yang tergolong berkebutuhan khusus ini mendapat perhatian yang sama dengan peserta didik reguler. Mereka juga berkewajiban mengikuti kegiatan ekstrakulikuler wajib (pramuka), dengan tujuan agar karakter mereka terbentuk dengan sempurna. Berdasarkan latar belakang di atas, penelitian ini bertujuan mendiskripsikan model Penguatan Pendidikan Karakter melalui kegiatan kepramukaan bagi peserta didik berkebutuhan khusus di Madrasah Ibtidaiyah Al-Hidayah Margorejo Surabaya. Pendekatan penelitian ini adalah diksriptif kualitatif. Teknik pengumpulan data dengan menggunakan teknik wawancara, observasi dan dokumentasi. Hasil penelitian ini bahwa model Penguatan Pendidikan Karakter berbasis Kepramukaan bagi Anak Berkebutuhan Khusus di Madrasah Ibtidaiyah Al-Hidayah Margorejo Surabaya dilakukan dengan mengaktualisasikan nilai-nilai karakter yang terkandung dalam dasa dharma melalui tiga model yaitu model blok, model aktualisasi, model reguler. Implementasi model blok yaitu kegiatan kepramukaan dilakukan melalui perkemahan setahun sekali ajaran baru. Model aktualisasi yaitu kegiatan kepramukan yang diselenggarakan pada tiap minggu. Model reguler adalah kegiatan sukarela berbasis minat peserta didik yang dilaksanakan di Gugus depan.
\end{abstract}

Kata Kunci: Penguatan Pendidikan Karakter, Kepramukaan, Anak Berkebutuhan Khusus, Madrasah Ibtidaiyah.

\footnotetext{
Abstract.

Madrasah Ibtidaiyah Al-HidayahMargorejo is one of the inclusive schools. There are four types of students with special needs in this school: students with learning difficulties, students with low vision,
} 
students with visual impairment, and students with speech delay. Students with special needs in this school get the same attention as regular students. They are also obliged to participate in extracurricular activities (scouts) with an aim that their characters are perfectly formed. Based on that description, the aim of this research is to describe the Model of Empowering Character Education through Scouting Activities for Students with Special Needs at Madrasah Ibtidaiyah AlHidayah Margorejo Surabaya. This research uses descriptive qualitative approach. Data Collection Techniques used in this research were interview, observation, and documentation. The results of this research indicate that Empowering Character Education through scouting activities for students with special needs at Madrasah Al-Hidayah Margorejo Surabaya is carried out by actualizing the character values in Dasa Dharma through three models: block model, actualization model, and regular model. Block model is implemented through camping program held once a year, specifically in the new academic year. Actualization model is implemented through scouting activities that is held every week. Regular model is implemented through voluntary activities based on students' interests conducted by gugus depan.

Keywords: Empowering Character Education, Scouting, Students with special needs, Madrasah Ibtidaiyah. 


\section{PENDAHULUAN}

Isu pendidikan karakter bukanlah hal baru yang diperbincangkan dalam dunia pendidikan di Indonesia. Sejak Indonesia merdeka hingga saat ini banyak formulasi-formulasi yang dicanangkan oleh Kementerian Pendidikan RI untuk membenahi karakter bangsa. Namun, pada saat itu belum menjadi sebuah fokus utama Kementerian Pendidikan RI dalam mendesain sebuah model pendidikan di Indonesia. Akhirnya, pada tahun 2010 Presiden Susilo Bambang Yudhoyono mencanangkan pendidikan karakter yang secara jelas telah dirumuskan dalam Rencana Strategis Kementerian Pendidikan dan Kebudayaan RI 2010-2014. ${ }^{1}$ Mulai saat itulah, desain pendidikan karakter mulai marak diperbincangkan secara khusus dan para praktisi pendidikan mulai marak melakukan penelitian terkait pendidikan karakter untuk melihat dan mengevaluasi implementasi pendidikan karakter di satuan pendidikan.

Beberapa peneliti yang fokus kajian terkait pendidikan karakter pada saat itu di antaranya, Mei Kusumawardi dalam penelitianya yang berjudul "Implementasi Nilai-Nilai Pendidikan Karakter Di Sekolah Menengah Kejuruan Negeri 4 Yogyakarta" dijalaskan bahwa dalam implementasi pendidikan karakter, khususnya di Sekolah Menengah Kejuruan Negeri 4 Yogyakarta diterapkan melalui 3 tahapan yaitu perencanaan, pelaksaan dan evaluasi. Dalam pelaksaannya terdapat kendala yaitu belum melibatkan semua guru dalam implementasi, harusnya pendidikan karakter diimplementasikan kepada semua jajaran yang ada di sekolah, semua pihak sekolah harus berpartisipasi dalam menginternalisasikan nilai karakter. ${ }^{2}$

Peneliti kedua, Binti Maunah dalam penelitiannya yang berjudul "Implementasi Pendidikan Karakter Dalam Pembentukan Kepribadian Holistik

${ }^{1}$ Rahmat Rifai Lubis, Historitas dan Dinamika Pendidikan Karakter di Indonesia, (jurnal An$\begin{array}{llllll}\text { Nahdhah, } & \text { Vol.1 } & \text { No. 2019), } & \text { 70, }\end{array}$ https://www.researchgate.net/publication/338570297__HISTORISITAS DAN DINAMIKA PENDIDIKAN_KARAKTER DI_INDONESIA, (accessed August 20, 2020).

${ }^{2}$ Mei Kusumawardani, Implementasi Nilai-Nilai Pendidikan Karakter Di Sekolah Menengah Kejuruan Negeri 4 Yogyakarta, Skripsi Program Studi pendidikan Teknik Boga Fakultas Teknik universitas Negeri Yogyakarta,2013, 99. 
Siswa" dijelaskan bahwa implementasi pendidikan karakter dilakukan melalui dua strategi yaitu strategi internal dan eksternal sekolah. Strategi internal yaitu segala aktifitas penanaman karakter yang dilakukan di dalam sekolah baik melalui integrasi dalam proses pembelajaran maupun ekstrakulikuler. Sedangkan strategi eksternal adalah pendidikan karakter di rumah dan masyarakat. Jika dua strategi ini diterapkan dengan maksimal maka pembentukan karakter anak akan terwujud. Sebaliknya, jika dua strategi tersebut tidak maksimal maka pendidikan karakter dalam implementasinya akan mengalami hambatan dalam mencapai tujuan. ${ }^{3}$ Selain dua penelitian yang telah penulis paparkan, masih banyak lagi tema penelitian yang mengkaji tentang pendidikan karakter, dan sampai pada akhirnya Kementerian Pendidikan dan Kebudayaan RI pada Kurikulum 2013 menguatkan kembali konsep pendidikan karakter yang lebih dikenal dengan sebuatan PPK (Penguatan Pendidikan Karakter).

Pada saat ini, implementasi pendidikan karakter dikemas dalam gerakan PPK (Penguatan Pendidikan Karakter) menjadikan pendidikan karakter sebagai bagaian terpenting atau perwujudan tujuan pendidikan nasional sehingga pendidikan karakter menjadi ujung dari pelaksanaan pendidikan dasar dan menengah. Lain dari itu, Gerakan PPK memadukan, memperdalam, memperluas, dan juga mengintegrasikan berbagai program dan kegiatan pendidikan karakter yang telah diimplementasikan sampai sekarang.

Berkaitan dengan hal tersebut, desain integrasi dapat berupa pemaduan kegiatan di dalam kelas, luar kelas di sekolah, dan di lingkungan masyarakat/komunitas; integrasi kegiatan intrakurikuler, kokurikuler, dan ekstrakurikuler; pelibatan antara warga sekolah, keluarga, dan masyarakat. Kegiatan pendalaman dan perluasan diwujudkan dalam penambahan dan pengintensifan kegiatan-kegiatan yang bertujuan pada pengembangan karakter peserta didik, penambahan kegiatan belajar siswa, dan pengaturan ulang jam belajar siswa di sekolah atau luar sekolah. Dengan demikian, gerakan Penguatan

\footnotetext{
${ }^{3}$ Binti Maunah, Implementasi Pendidikan Karakter Dalam PembentukanKepribadian Holistik Siswa, Jurnal Pendidikan Karakter Tahun V , Nomor 1 April 2015.,99, https://journal.uny.ac.id/index.php/jpka/article/view/8615, (accessed August 20, 2020).
} 
Pendidikan Karakter sebagai bentuk untuk mewujudkan Nawacita dan Gerakan Revolusi Mental dan menjadi inti kegiatan pendidikan yang dapat mendukung gerakan revolusi karakter bangsa. ${ }^{4}$

Merujuk pada uraian di atas, penulis dalam penelitian ini menguraikan tentang bagaimana Madrasah Ibtidaiyah Al-Hidayah Margorejo Surabaya mengembangkan model Penguatan Pendidikan Karakter yang diterapkan melalui kegiatan ekstrakulikuler kepramukaan bagi peserta didik berkebutuhan khusus. Terdapat beberapa penelitian terdahulu dengan fokus pembahasan tentang pendidikan karakter melalui kepramukaan yang telah dipublikasikan di antaranya: Pertama, Suprihatin telah melakukan penelitian tentang Penguatan pendidikan Karakter melalui revitalisasi gerakan pramuka. Melalui pendekatan studi kasus, ia mendiskripsikan program revitalisasi kegiatan pramuka dalam penguatan pendidikan karakter serta memaparkan kendala-kendala yang dihadapi dalam implementasinya di SMP Negeri 1 Trucuk Kabupaten Klaten. Dalam penelitiannya dihasilkan bahwa nilai-nilai karakter yang dikembangkan dalam kegiatan kepramukaan yaitu jujur, cerdas, tangguh religius, peduli lingkungan dan peduli. ${ }^{5}$

Kedua, Siti Hartati dalam karyanya memaparkan bagaimana pembinaan karakter siswa melalui kegiatan kepramukaan di SMPN 5 Terbanggi-Besar Lampung Tengah. Dalam penelitiannya, ia mendiskripsikan bahwa kegiatan pembinaan karakter siswa dilakukan melalui kegiatan kepramukaan yang berupa penugasan, keteladanan, ceramah, hukuman dan sanksi. Sedikit berbeda dengan penelitian yang dilakukan sebelumnya, jika Suprihatin lebih menfokuskan pada nilai apa yang dikembangkan dalam kegiatan penguatan

${ }^{4}$ Hendarman, dkk, Konsep dan Pedoman Penguatan Pendidikan Karakter Tingkat Sekolah Dasar dan Sekolah Menengah Pertama, (Jakarta: Kementerian Pendidikan dan Kebudayaan Republic Indonesia), 5-6.

${ }^{5}$ Suprihatin, Penguatan pendidikan Karakter Melalui Revitalisasi Gerakan Pramuka (Studi Kasus kegiatan Kepramukaan Kelas VII SMP Negeri 1 Trucuk Kabupaten Klaten 2012/2013, (Surakarta: Fakultas Keguruan dan Ilmu Pendidikan Universitas Muhammadiyah Surakarta, 2014). 
pendidikan karakter, tapi kali ini lebih menfokuskan pada kegiatan apa yang dikembangkan untuk menanamkan nilai karakter. ${ }^{6}$

Ketiga, Marzuki dan Lisa Hapsari dalam karyanya yang berjudul "Pembentukan Karakter Siswa Melalui Kegiatan Kepramukaan Di MAN 1 Yogyakarta" memaparkan bentuk-bentuk pembinaan karakter siswa dan mendiskripkan hambatan serta upaya dalam melakukan pembinaan karakter siswa. Hasil dari panelitian ini bahwa bentuk pembinaan karakter siswa melalui kegiatan kepramukaan diselenggarakan dengan mengintensifkan peran pembina pramuka sebagai pembimbing, teman sejawat atau mitra dalam memberikan dukungan dan memfasilitasi siswa dengan kegiatan yang modern, menarik, dan menantang melalui metode pengamalan kode kehormatan pramuka pada setiap kegiatan; kegiatan belajar sambil melakukan, berkelompok, bekerja sama, dan berkompetisi; kegiatan di alam terbuka seperti perkemahan; penghargaan berupa tanda kecakapan bantara dan laksana; serta satuan terpisah ambalan putra dan putri. Hambatan dalam kegiatan pembinaan adalah minimnya pembimbingan guru terhadap kegiatan pramuka dan sebagian besar peserta didik tidak memiliki minat untuk mengikuti kegiatan ekstrakulikuler pramuka. Usaha yang dilakukan untuk mengatasinya dengan menanamkan sifat ikhlas kepada para guru untuk melakukan pembimbingan dan menciptakan kegiatan yang menarik dan menantang siswa. Hasil penelitian in memiliki fokus kajian yang sama dengan penenlitian yang dilakukan oleh Suprihatin. $^{7}$

Keempat, Sa'ada Erliani dalam tulisannya memaparkan peran kegiatan kepramukaan dalam membentuk karakter kepedulian sosial dan kemandirian. Fokus penelitian ini pada dua nilai karakter yang dilakukan melalui pemahaman, keikhlasan, kerja keras, berjuang dengan sungguh-sungguh, ketaatan, pengorbanan, komitmen, konsisten, persaudaraan, dan kepercayaan.

${ }^{6}$ Siti Hartati, Pembinaan Karakter Siswa Melalui Kegiatan Kepramukaan Di SMP Negeri 5 Terbanggi Besar Lampung Tengah, (Lampung: Fakultas Tarbiyah dan Keguruan Universitas Islam Negeri Raden Intan Lampung, 2018).

${ }^{7}$ Marzuki; Lisa Hapsari, Pembentukan Karakter Siswa Melalui Kegiatan Kepramukaan Di MAN 1 Yogyakarta, Jurnal Pendidikan Karakter Tahun V, Nomor 2, Oktober 2015, 142-156, https://journal.uny.ac.id/index.php/jpka/article/view/8619, (accessed August 6, 2020). 
Model Penguatan Pendidikan Karakter Berbasis Kepramukaan Bagi Peserta Didik

Adapun kegiatan yang dilakukan dalam penanaman karakter yaitu keteladanan, pembiasaan, teguran dan penghargaan. Melalui kegiatan ini peran pramuka dalam membentuk karakter yaitu gerakan pramuka sebagai bekal ketrampilan, melatih siswa untuk taat pada norma sosial, dan kegiatan meningkatkan intelegensi. ${ }^{8}$

Kelima, Indah Ratnawati dkk dalam penelitiannya yang berjudul "Manajemen Pendidikan Karakter Peserta Didik Melalui Kegiatan ekstrakulikuler Pramuka". Penelitian ini berbeda dengan penelitian sebelumnya, kajian dalam penelitian ini difokuskan pada sisi manajemen pendidikan karakter. Hasil penelitian ini menunjukkan bahwa manajemen pendidikan karakter melalui kegiatan pramuka dilakukan melalui beberapa tahapan manajemen yaitu perencaan pendidikan karakter, pengorganisasian pendidikan karakter, pelaksanaan pendidikan karakter, dan pemantauan pendidikan karakter. ${ }^{9}$

Dari kelima penelitian yang teruraikan di atas, titik beda dengan penelitian yang penulis angkat dalam artikel ini adalah pada kajian yang lebih difokuskan pada penerapan penguatan pendidikan karakter berbasis kepramukaan pada peserta didik berkebutuhan khusus yang terdiri dari kesulitan belajar, low vision, tuna daksa dan speech delay yang berada di MI Alhidayah Margorejo Surabaya dan inilah yang menjadi nilai kebaruan dalam penelitian ini jika dibandingkan dengan beberapa penelitian atau studi terdahulu yang terkait tentang pendidikan karakter. Peneliti melakukan hal ini dengan tujuan agar formulasi penguatan pendidikan karakter melalui kegiatan pramuka tidak hanya sebatas diterapkan pada siswa normal, akan tetapi siswa berkebutuhan khusus juga harus menjadi perhatian dalam implementasi PPK khususnya melalui kegiatan pramuka.

${ }^{8}$ Sa'adah Erliani, Peran Gerakan Pramuka Untuk Membentuk Karakter Kepedulian Sosial dan Kemandirian (Studi Kasus di SDIT Ukhwah dan MIS An-Nuriyyah 2 Banjarmasin), Jurnal Madrasah Ibtidaiyah Muallimuna Vol. 2 No. 1 Oktober 2016. 34-46, https://jurnal.uinantasari.ac.id/index.php/adzka/article/view/2020, (accessed August 7, 2020).

9 Indah Ratnawati dkk, Manajemen Pendidikan Karakter Peserta Didik Melalui Kegiatan ekstrakulikuler Pramuka, JAMP: Jurnal Administrasi dan Manajemen Pendidikan, Volume 1, Nomor 3 September 2018: 284-292, http://journal2.um.ac.id/index.php/jamp/article/view/3690 (accessed August 20, 2020) 
Karakter dalam bahasa Yunani dikenal dengan istilah "Charassein" yang memiliki makna mengukir sampai membentuk sebuah pola. ${ }^{10}$ Sedangkan dalam Kamus Bahasa Indonesia kata "karakter" memiliki makna akhlak, sifat kejiwaan atau budi pekerti. ${ }^{11}$ Dalam bahasa Arab, karakter memiliki makna yang sama dengan kata "akhlak", yang artinya watak dasar, perilaku, moral, perangai, tabi'at, watak dasar, kebiasaan, peradaban yang baik dan agama. ${ }^{12}$ Adapun dalam buku panduan pengembangan pendidikan budaya dan karakter bangsa yang diterbitkan oleh Kementrian Pendidikan Nasional Badan Penelitian Pusat Kurikulum dijelaskan bahwa definisi karakter adalah kepribadian, watak, tabiat, atau perilaku seseorang yang terwujud dari manifestasi nilai-nilai kebaikan (virtues) yang dijadikan rujukan atau landasan untuk melakukan kegiatan sehari-hari. Nilai kebajikan yang diwujudkan dalam kehidupan sehari-hari seperti jujur, menghargai pendapat orang lain, sopan santun, gotong royong dan lain-lain. ${ }^{13}$ Dari beberapa paparan tentang definisi karakter di atas, dapat disimpulkan bahwa karakter adalah karakteristik kepribadian seseorang yang merupakan pembeda antara setiap individu yang terwujud dalam setiap perilaku dalam kehidupan sehari- hari.

Sesuai dengan definisi pendidikan dan definisi karakter yang terpaparkan di atas, maka pengertian pendidikan karakter adalah usaha dalam mewujudkan kebiasaan terpuji pada diri anak sejak usia dini atau sistem internalisasi nilainilai karakter yang terdiri dari beberapa komponen pengetahuan, kemauan, dan perilaku untuk mewujudkan nilai-nilai terpuji pada Tuhan Yang Maha Esa, sesama, lingkungan, diri sendiri, bangsa dan negara agar tercipta manusia paripurna $^{14}$

\footnotetext{
${ }^{10}$ Ratna Megawangi, Pendidikan Karakter: Solusi Yang Tepat Untuk Membangun Bangsa. (Jakarta: Indonesia Heritage Foundation, 2004), 23.

${ }^{11}$ Em Zul Fajri, Ratu Aprillia, Kamus Lengkap Bahasa Indonesia, (Jakarta: Difa Publisher), 422.

${ }^{12}$ Hans Wehr, A Dictionary of Modern Written Arabic, ed. J. Milton Cowan (Beirut: Maktabah Lubnan, 1980), 258; Poerwadarminta, Катиs Umum, 25; Dewan Redaksi Ensiklopedi Islam, Ensiklopedi Islam I (Jakarta: PT. Ichtiar Baru Van Hoeve, 1994), 102-103.

${ }^{13}$ Kementrian Pendidikan Nasional Badan Penelitian dan Pengembangan Pusat Kurikulum, Pengembangan Pen.didikan Budaya dan Karakter Bangsa (Jakarta: 2010), 3

${ }^{14}$ Ratna Megawangi, Pendidikan Karakter, 23.
} 
Konsep Penguatan Pendidikan Karakter adalah gerakan dalam bidang pendidikan di sekolah untuk menginternalisasikan nilai-nilai karakter pada diri peserta didik melalui kegiatan transformasi, transmisi, dan pengembangan potensi peserta didik yang diwujudkan melalui optimalisasi keseimbangan oleh hati (spiritual dan etika), olah rasa (estetik), olah pikir (literasi dan numerasi), dan olah raga (kinestetik) yang sesuai dengan nilai-nilai Pancasila. Dalam implementasi PPK keterlibatan, kerja sama dan dukungan sekolah, keluarga, dan masyarakat harus terjalin dengan baik.

Gerakan Penguatan Pendidikan Karakter terfokus pada struktur sistem pendidikan nasional. Ada tiga struktur yang dapat memperkuat gerakan PPK, yaitu:1) Sruktur Program yang terdiri dari jenjang dan kelas, lingkungan sekolah, dan penguatan kapasitas kompetensi guru. 2) Struktur Kurikulum yang tersusun dari beberapa kegiatan yaitu, kegiatan pembentukan karakter terintegrasi dalam kegiatan intrakurikuler, kegiatan kokurikuler, dan kegiatan ekstrakurikuler. 3) Struktur Kegiatan yang terdiri dari berbagai program dan kegiatan yang dapat mensinergikan empat dimensi pengolahan karakter yang digagas oleh Ki Hadjar Dewantara yaitu olah hati, raga, pikir, dan rasa. ${ }^{15}$

Desain implementasi Penguatan Pendidikan Karakter pada satuan pendidikan dapat dilakukan melalui kegiatan ekstrakurikuler. Kegiatan ekstrakulikuler adalah kegiatan pengembangan karakter peserta didik yang diselenggarakan di luar jadwal jam pelajaran. Ekstrakurikuler bertujuan untuk mengembangkan dan mengoptimalisasikan minat dan bakat peserta didik dengan mempertimbangkan karakteristik peserta didik, kearifan lokal, serta faktor dukung yang ada. Salah satu ektrakulikuler yang wajib dilaksanakan pada jenjang Sekolah Dasar/Madrasasah Ibtidaiyah adalan pramuka. Pengertian kepramukaan adalah suatu proses pendidikan yang diselenggarakan di luar lingkungan sekolah dan keluarga dalam wujud kegiatan yang menarik, menyenangkan, menarik, menyehatkan, terarah, terukur, praktis yang diselenggarakan dialam terbuka dengan berpegang teguh pada prinsip dasar Kepramukaan dan Metode

\footnotetext{
${ }^{15}$ Hendarman, dkk, Konsep dan Pedoman Penguatan, 12.
} 
Kepramukaan, yang tujuan akhirnya dari kegiatannya adalah pembentukan budi pekerti luhur dan kepribadian peserta didik yang unggul.

Kata kepramukaan jika disandikan dengan kata pendidikan (Pendidikan Kepramukaan) adalah proses pembentukan kepribadian, kecakapan hidup, dan akhlak mulia pramuka melalui penghayatan dan pengamalan nilai nilai kepramukaan. ${ }^{16}$ Jika mencermati definisi kepramukaan dan pendidikan kepramukaan, maka dapat disimpulkan bahwa kegiatan kepramukaan bertujuan untuk memperkuat karakter peserta didik. Sebagaimana yang tertuang dalam, Dwi Satya, Dwi Dharma, Try Satya dan Dasadharma.

Adanya Peraturan Menteri Pendidikan dan Kebudayaan Republik Indonesia Nomor 64 Tahun 2014 Tentang Pendidikan Kepramukaan Sebagai Kegiatan Ekstrakulikuler Wajib Pada Pendidikan Dasar dan Pendidikan Menengah, maka semua peserta didik pada jenjang Pendidikan Dasar dan Menengah wajib untuk mengikuti kegiatan kepramukaan, tidak terkecuali peserta didik yang berkebutuhan khusus. Peserta didik yang tergolong berkebutuhan khusus yaitu tunanetra, tunarungu, tunawicara, tunagrahita, tunadaksa, tunalaras, berkesulitan belajar, lamban belajar, autis, memiliki gangguan motorik, menjadi korban penyalahgunaan narkoba, obat terlarang, dan zat adiktif lainnya, memiliki kelainan lainnya, tunaganda. ${ }^{17}$

Berkaitan dengan keragaman beserta didik berkebutuhan khusus, tujuan penelitian ini mendiskripsikan model penguatan pendidikan karakter berbasis kepramukkaan bagi peserta didik berkebutuhan khusus di Madrasah Ibtidaiyah. Pedoman nilai karakter yang menjadi rujukan dalam penelitian ini yaitu yang terdapat dalam Dwi Satya dan Dwi Dharma sebagaimana dalam table berikut:

\footnotetext{
${ }^{16}$ Lampiran Peraturan Menteri Pendidikan dan Kebudayaan Republik Indonesia Nomor 64 Tahun 2014, Pedoman Pendidikan Kepramukaan Sebagai Kegiatan Ekstrakulikuler Wajib Pada Pendidikan Dasar dan Pendidikan Menengah, 4

${ }_{17}$ Peraturan Menteri Pendidikan Nasional Nomor 70 Tahun 2009 Tentang Pendidikan Inklusif Bagi Peserta Didik Yang Memiliki Kelainan dan Memiliki Kecerdasan Dan/Atau Bakat istimewa, 2
} 
Tabel 1 Pedoman Nilai Karakter dalam Dwi Satya dan Dwi Dharma

\begin{tabular}{ll}
\hline \multicolumn{1}{c}{ Dwi Satya } & \multicolumn{1}{c}{ Dwi Dharma } \\
\hline $\begin{array}{l}\text { 1. Siaga berbakti kepada ayah } \\
\text { bunda. }\end{array}$ & 1. Aku berjanji akan bersungguh-sungguh \\
menjalankan kewajibanku terhadap Tuhan dan \\
$\begin{array}{ll}\text { 2. Siaga berani dan tidak putus } \\
\text { asa. }\end{array}$ & Negara Kesatuan Republik Indonesia, dan \\
& mengikuti tata krama keluarga. \\
& 2. Setiap hari berbuat kebaikan \\
\hline
\end{tabular}

\section{METODE PENELITIAN}

Penelitian ini menggunakan pendekatan diskriptif kualitatif. Pendekatan diskriptif kualitatif digunakan untuk mendiskripsikan bagaimana model penguatan pendidikan karakter berbasis kepramukaan bagi peserta didik berkebutuhan khusus serta mendiskripsikan nilai-nilai karakter yang dikembangkan dalam kegiatan kepramukaan. Teknik pengumpulan data dalam penelitian ini adalah, wawancara, dokumentasi, dan observasi. Adapun teknik analisis data yang digunakan adalah teknik analisis data kualitatif dengan menyiapkan data berupa rekap proses penguatan pendidikan katrakter berbasis kepramukaan bagi peserta didik berkebutuhan khusus, kemudian membuat garis besar kerangka model penguatan pendidikan karakter melalui kegiatan pramuka bagi peserta didik berkebutuhan khusus serta mendiskripsikan nilai-nilai karakter yang dikembangkan dalam kegiatan kepramukaan dan membuat kesimpulan. Penelitian ini dilakukan di Madrasah Ibtidaiyah Al-Hidayah Margorejo Surabaya. Subjek penelitian ini peserta didik berkebutuhan khusus di MI Al-Hidayah yang tergolong kesulitan belajar, low vision, tuna daksa dan speech delay.

\section{HASIL DAN PEMBAHASAN}

\section{Peserta Didik Berkebutuhan Khusus di Madrasah Ibtidaiyah Al-}

\section{Hidayah Margorejo}

Madrasah Ibtidaiyah (MI) Al-Hidayah Margorejo mulai menampakkan eksistensinya pada tahun 1972 dengan model pendidikan reguler. Dalam perkembangannya, pada tahun 2015 madrasah Al-Hidayah 
melalui visinya "Madrasah Berkarakter dan Unggul Tanpa Diskriminasi" mengembangkan program pendidikannya dengan model madrasah inklusi (model madrasah yang menyelenggarakan pendidikan dengan sistem menggabungkan peserta didik reguler/normal dengan peserta didik berkebutuhan khusus dalam satu lingkungan pendidikan) ${ }^{18}$. Dengan model pendidikan inklusi, peserta didik di Madrasah Ibtidayah yang keseluruhannya berjumlah 62 pesetra didik yang terdiri dari menjadi dua golongan, yaitu 51 peserta didik reguler dan 11 peserta didik berkebutuhan khusus. ${ }^{19}$ Kesebelas peserta didik berkebutuhan khusus di MI dikelompokkan menjadi beberapa hambatan yaitu kesulitan belajar, lamban belajar, low vision, tunadaksa dan speech delay. Berdasarkan hasil identifikasi dan asessment wali kelas, peserta didik yang mengalami kesulitan belajar dan lamban belajar memiliki indikator kemampuan literasi yang rendah.

Sejalan dengan pendapat David Smith bahwa seseorang yang mengalami kesulitan belajar (learning disability) memiliki beragam hambatan di antaranya hambatan dalam berbicara, membaca, menulis, berpikir atau kemampuan matematis dan berbicara. Hambatan-hambatan ini bersifat internal yang diprediksi penyebabnya adalah tidak berfungsi saraf pusat. Hambatan dalam mengkondisikan sikap diri sendiri, persepsi sosial, dan interaksi sosial. Kesulitan belajar dapat terjadi bersamaan atau disertai dengan kondisi kecatatan (handicapped) lainnya, misalnya gangguan sensorik (sensory impairment), terbelakang mental (mental retardation), emosi yang tidak stabil dan dialami dengan serius (serious emotional distur rqbance)-atau pengaruh eksternal misalnya perbedaan budaya, pembelajajaran yang kurang tepat. ${ }^{20}$

18 Zumrotul Mukaffa, Pengembangan Model Madrasah Inklusif (Studi Atas Kesiapan dan Model Pengembangan Kurikulum Madrasah Inklusif MI Al-Hidayah Margorejo Surabaya), Edukasia,"Jurnal Penelitian Pendidikan Islam", Vol. 12, No. 1 Februari 2017, 8, https://journal.iainkudus.ac.id/index.php/Edukasia/article/view/2051, (accessed August 20, 2020).

${ }^{19}$ Wawancara, 10 Juni 2019, Tias, Guru MI Al-Hidayah

${ }^{20}$ J. David Smith, Inklusi Sekolah Ramah Untuk Semua, (Bandung: Penerbit Nuansa, 2006), hlm.75. 
Model Penguatan Pendidikan Karakter Berbasis Kepramukaan Bagi Peserta Didik

Sedangkan, menurut Nurul Hidayati Rofiah anak yang mengalami lamban belajar (slow learner) adalah anak dengan kondisi intelektual yang sedikit d ibawah normal, akan tetapi tidak termasuk anak tuna graihita. Hasil tes kecerdasan pada anak yang mengalami lamban belajar diperoleh hasil antar 70-89. ${ }^{21}$ Selain karakteristik yang dipaparkan oleh Nurul, Ana Lisdiana juga menjelaskan bahwa anak slow learner memiliki motivasi belajar yang rendah." Rendahnya motivasi belajar pada anak yang lamban belajar tersebut salah satunya disebabkan dari kegagalan yang sering dialami dalam belajar, seperti kegagalan dalam mencapai nilai yang memuaskan. Hambatan-hambatan yang mereka alami disebabkan faktor utama tingkat kecerdasan IQ antar 70-89 atau 70-90, sehingga anak dengan lamban belajar tidak mampu berkembang seperti anak normal pada umumnya. $^{22}$

Lain halnya dengan peserta didik yang mengalami hambatan low vision, menurut wali kelas, peserta didik low vision mengalami gangguan visual. Hambatan ini tidak mempengaruhi tingkat intelegensi peserta didik, hanya saja ia membutuhkan alat bantu ketika melihat. Hal ini sejalan dengan pendapat yang diungkapkan oleh Hayes dalam karyanya yang dikutip oleh Tommy Hari Firmanda bahwa anak yang memiliki hambatan penglihatan tidak secara otomatis berpengaruh pada rendahnya tingkat intelegensi anak. Hal ini disebabkan daya ingat yang kuat dipengaruhi oleh kemampuan konseptual (conceptual abilities), meskipun tingkat visual kurang baik atau terganggu. ${ }^{23}$ Selain karakteristik tersebut, menurut Marzolf dalam karya Busono yang dikutip oleh Tommy bahwa anak yang mengalami hambatan visual atau penglihatan pada tingkat apapun akan memiliki hambatan dalam

21 Nurul Hidayati Rofiah, Penerapan Metode Pembelajaran Peserta Didik Slow Learner, Naturalistic: Jurnal Kajian Penelitian Pendidikan dan Pembelajaran No. 2, 1 Oktober 2017, 94-107, https://journal.umtas.ac.id/index.php/naturalistic/article/view/108, (accessed September 18, 2020).

${ }^{22}$ Mutmainah, Motivasi Belajar Siswa Slow Learner, Jurnal Bimbingan dan Konseling Ar-Rahman, Volume 3, No. 2, 2017, 7, https://ojs.uniska-bjm.ac.id/index.php/BKA/article/view/1038, (accesed August 6, 2020).

${ }^{23}$ Tommy Hari Firmanda, "Penyesuaian Diri Penyandang Low Vision dalam Melewati Pendidikan di Perguruan Tinggi” Jurnal Psikologi Tabularasa Vol. 9, NO.1, April, 2014, 3. 
masalah penyesuaian pribadinya dan jika tidak ditangani dengan baik akan mengakibatkan pada gangguan kejiwaan jasmaniah atau yang disebut dengan somatopsikologik. ${ }^{24}$

Peserta didik berkebutuhan khusus di MI Al-Hidayah selain kesulitan belajar, lamban belajar dan low vision, terdapat juga tunadaksa dan speech delay. Peserta didik yang tergolong tunadaksa memiliki ciri dan karakteristik di antaranya adalah mengalami cacat tubuh, dalam hal ini yang diderita oleh peserta didik MI Al-Hidayah yaitu cacat pada tangan sebelah kanan. Ia mengalami hambatan ketika menulis yang mengakibatkan sering tertinggal dalam melakukan kegiatan yang berkaitan dengan motorik kasar, motorik halus seperti ketika menlis, menggambar, melakukan olah raga, dan praktik psikomotor lainnya. ${ }^{25}$ Menurut hasil wawancara dengan wali kelas, hambatan ini tidak mempengaruhi tingkat intelegensi peserta didik. Kondisi peserta didik ini sejalan dengan pendapat Jati Rinakri Atmajabahwa tunadaksa adalah anak yang memiliki anggota tubuh tidak sempurna, satau yang dikenal dengan istilah cacat tubuh dan cacat fisik. ${ }^{26}$

Peserta didik yang tergolong speech delay (keterlambatan bicara) duduk di kelas 1, ia memiliki ciri- ciri khusus yaitu susah dalam bicara yang mengakibatkan sulit untuk berkomunikasi, berliterasi dan bersosialisasi. Karakteristik yang dialami peserta didik ini sejalan dengan pendapat yang diungkapkan oleh Hurlock yang dikutip oleh Khoiriyah dan kawan-kawan bahwa jika seseorang memiliki tingkat perkembangan bicara atau bahasa pada level rendah atau dibawah rata-rata tingkat kualitas perkembangan bicara atau bahasa seseorang pada umumnya atau seumurnya, maka akan berpengaruh pada hubungan interaksi sosial seseorang. ${ }^{27}$

\footnotetext{
${ }^{24}$ Ibid., 5.

${ }^{25}$ Wawancara Wali Kelas 1 Ustadzah Rohma, 12 Agustus 2019.

${ }^{26}$ Jati Rinakri Atmaja, Pendidikan dan Bimbingan Anak Berkebutuhan Khusus, (Bandung: PT Remaja Rosdakarya, 2019), Cet. 2, hlm. 127.

${ }^{27}$ Khoiriyah;, Anizar Ahmad ;,Dewi Fitriani, Model Pengembangan Kecakapan Berbahasa Anak Yang Terlambat Berbicara (Speech Delay), Jurnal Ilmiah Mahasiswa Pendidikan Anak Usia Dini, 1 (1), Agustus 2016, http://garuda.ristekbrin.go.id/documents/detail/446375, (accessed September 2, 2020).
} 
2. Model Penguatan Pendidikan Karakter Berbasis Kepramukaan Bagi Peserta Didik Berkebutuhan Khusus di MI Al-Hidayah Margorejo Surabaya

Kegiatan ekstrakulikuler di MI Al-Hidayah Margorejo Surabaya dilaksanakan pada hari Sabtu jam 09.00-11.00. Kegiatan ekstrakulikuler ini wajib diikuti oleh semua peserta didik MI Al-Hidayah, tanpa terkecuali peserta didik berkebutuhan khusus. Mereka juga wajib mengikuti kegiatan ekstrakulikuler kepramukaan dengan modifikasi-modifikasi kegitan. Jika mereka tidak mampu untuk mengikuti kegiatan pramuka seperti yang harus dilakukan oleh peserta didik reguler, maka pembina pramuka melakukan modifikasi kegiatan seperti pada kolom di bawah ini

Tabel 2 Modifikasi Kegiatan Penguatan Pendidikan Karakter bagi Peserta Didik Berkebutuhan Khusus

\begin{tabular}{llll}
\hline Jenis & Tujuan & Peserta Didik & Peserta didik \\
Kegiatan & /karakter yang & reguler/normal & Berkebutuhan \\
& ditumbuhkan & & khusus \\
& dalam & & \\
& Permainan & & \\
\hline Permainan & Untuk siswa & Setiap anggota & Untuk siswa \\
Tongkat & reguler permainan & memegangi & berkebutuhan \\
Stick & ini diperuntuk & seutas tali, & khusus (low \\
Goyang & untuk melatih & kemudian & vision) kegiatan \\
& kekompakan, siap & letakkan tongkat & ini dimodifikasi \\
& menghadapi & bamboo pada & dengan model \\
& rintangan, rela & utas tali dan & siswa tetap \\
& memberikan & diikatkan hingga & menggunakan \\
& sesuatu kepada & kuat. Setiap & media tongkat \\
& orang lain. & anggota & dan tali yang \\
& Sedangkan bagi & menempuh & diikatkan. \\
& siswa ABK, & sebuah & Namun, siswa \\
& permainan ini & perjalanan yang & tidak melalui \\
\hline & & & \\
\hline
\end{tabular}




\begin{tabular}{|c|c|c|c|}
\hline $\begin{array}{l}\text { Jenis } \\
\text { Kegiatan }\end{array}$ & $\begin{array}{l}\text { Tujuan } \\
\text { /karakter yang } \\
\text { ditumbuhkan } \\
\text { dalam } \\
\text { Permainan }\end{array}$ & $\begin{array}{l}\text { Peserta Didik } \\
\text { reguler/normal }\end{array}$ & $\begin{array}{l}\text { Peserta didik } \\
\text { Berkebutuhan } \\
\text { khusus }\end{array}$ \\
\hline & $\begin{array}{l}\text { untuk melatih } \\
\text { karakter } \\
\text { keseimbangan dan } \\
\text { ketelitian dalam } \\
\text { mmenyelesaikan } \\
\text { suatu pekerjaan. }\end{array}$ & $\begin{array}{l}\text { banyak sekali } \\
\text { rinntangannya } \\
\text { dan setiap } \\
\text { anggota harus } \\
\text { kerja keras } \\
\text { melalui rintangan } \\
\text { agar tongkat } \\
\text { yang } \\
\text { dipegangnya } \\
\text { tidak jatuh. Regu } \\
\text { yang menjadi } \\
\text { pemenang adalah } \\
\text { regu yang lebih } \\
\text { awal sampai pada } \\
\text { pos dan } \\
\text { tnggaktnya tidak } \\
\text { jatuh }\end{array}$ & $\begin{array}{l}\text { sebuah perjalanan } \\
\text { yang banyak } \\
\text { rintangan, akan } \\
\text { tetapi siswa hanya } \\
\text { berjalan mulai } \\
\text { dari garis strat } \\
\text { sampai finish } \\
\text { dengan } \\
\text { membawah } \\
\text { tongkat dengan } \\
\text { dua jarinya dan } \\
\text { tidak boleh jatuh } \\
\text { tongkat yang } \\
\text { dipegangnya. }\end{array}$ \\
\hline
\end{tabular}

Pada jenjang pendidikan dasar khususnya di MI Al-Hidayah, peserta didik pada kelas 1 dan kelas 4 pada tingakatan pramuka siaga (usia 7-10 tahun). Peserta didik pada kelas 5 dan kelas 6 tingkatan pramuka penggalang (usia 11-15 tahun) ${ }^{28}$ Kepala MI Al-Hidayah mewajibkan kegiatan ekatrakulikuler pramuka kepada semua peserta didik sebagai perwujudan implementasi Peraturan Menteri Pendidikan dan Kebudayaan Republik Indonesia Nomor 63 tahun 2014 tentang Pendidikan

${ }^{28}$ Wawancara Fitri Lutfi Febriani, 10 September 2019 
Model Penguatan Pendidikan Karakter Berbasis Kepramukaan Bagi Peserta Didik

Kepramukaan Sebagai Ekstrakulikuler Wajib. ${ }^{29}$ Sebagaimana dalam peraturan tersebut digambarkan dalam desain Induk Pendidikan Kepramukaan sebagai ekstrakulikuler wajib pada pendidikan dasar dan menengah. Robert E. McGrath mengatakan bahwa content program tertentu dapat mengarahkan pada strategi pendidikan tertentu, dan syarat program yang dapat mengarahkan siswa pada pendidikan karakter menurutnya adalah: 1) programnya berbasis sekolah; 2) programnya terstruktur; 3) programnya membawa atribut psikologis yang positif; 4) programnya membahas identitas (bertujuan untuk peningkatan pertumbuhan pribadi); 5) programnya membahas pertumbuhan moral; 6) programnya membahas pertumbuhan secara holistic (keseluruhan); 7) programnya membahas practical wisdom yaitu dengan menerapkan unsurunsur karakter yang disengaja dan bijaksana untuk situasi tertentu. ${ }^{30}$ Dan ketujuh program ini terdapat dalam kegiatan kepramukaan yang juga didapatkan siswa di sekolah.

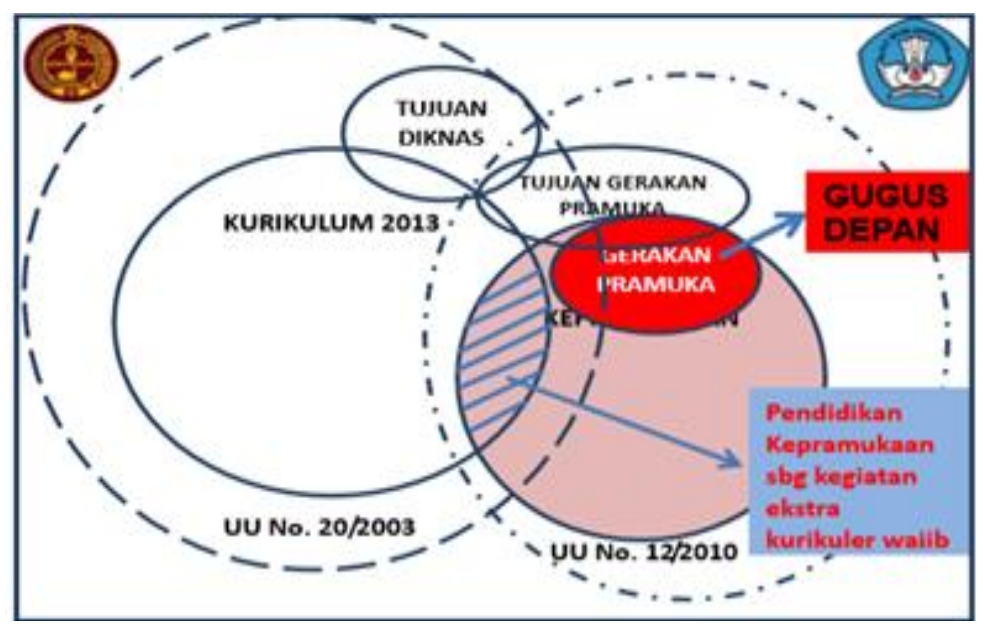

Gambar 1 Desain Induk Pendidikan Kepramukaan

${ }^{29}$ Wawancara Kepala MI Al-Hidayah, M.Reza Abady, 10 September 2019.

30 . Robert E. McGrath. What Is Character Education?: Development of a Prototype. Journal of Character Education Vol. 14, No. 2, 2018, https://eric.ed.gov/?id=EJ1199511 (accessed September $18,2020)$ 
Dalam penyelenggaraan kegiatan pramuka, pihak madrasah mengintengrasikan nilai-nilai karakter utama yang diadopsi dari nilai-nilai yang terkandung dalam Tri Satya, Dwi Stya dan Dwi Dharma. Adapun secara rinci nilai-nilai karakter tersebut sebagaimana dalam tabel di bawah ini.

\section{Tabel 3 Nilai Karakter dalam Kegiatan Pramuka di MI Al-Hidayah Margorejo}

\begin{tabular}{llll}
\hline $\begin{array}{l}\text { Nilai Karakter Dalam Dwi } \\
\text { Satya }\end{array}$ & $\begin{array}{l}\text { Nilai Karakter } \\
\text { Dharma }\end{array}$ & Dalam & Dwi \\
\hline Berbakti kepada orang tua dan & Giat belajar & \\
guru & & \\
Pemberani & Disiplin & \\
Pantang menyerah/kerja keras & Taat beribadah & \\
Sopan santun & Cinta lingkungan & \\
\hline
\end{tabular}

Nilai-nilai karakter yang terpaparkan dalam tabel di atas wajib terintegasikan pada semua aktivitas kegiatan pramuka yang dilakukan pada semua peserta didik tanpa terkecuali peserta didik berkebutuhan khusus.

Secara umum, desain Penguatan Pendidikan Karakter berbasis Kepramukaan bagi Anak Berkebutuhan Khusus di Madrasah Ibtidaiyah AlHidayah Margorejo Surabaya dilakukan dengan mengaktualisasikan nilainilai karakter yang terkandung dalam Dwi Satya, Dwi Dharma melalui tiga model yaitu model blok, model aktualisasi dan model reguler. Tiap model terdiri atas bermacam kegiatan yang fleksibel dan kreatif. Jorun BuliHolmberg dan Sujathamalini Jeyaprathaban dalam penelitiannya mengatakan bahwa kegiatan praktik yang fleksibel dan kreatif merupakan kegiatan praktik terbaik yang memenuhi persyaratan belajar anak berkebutuhan khusus. ${ }^{31}$ Oleh sebab itu, tiga model yang terkandung dalam

\footnotetext{
31 . Jorun BuliHolmberg dan Sujathamalini Jeyaprathaban.Effective Practice in Inclusive and Special Needs Education. International Journal of Special Education Vol 31, No: 1, 2016, https://scinapse.io/papers/2549013895, (Accessed September 18, 2020).
} 
Model Penguatan Pendidikan Karakter Berbasis Kepramukaan Bagi Peserta Didik

Dwi Satya dan Dwi Dharma ini akan menciptakan banyak interaksi sehingga semakin banyak mengasah nilai-nilai karakter peserta didik anak berkebutuhan khusus.

Nilai-nilai karakter yang didapatkan siswa dalam kegiatan praktik adalah kemandirian, kedisiplinan, gotong-royong, kedisiplinan, saling menghormati, kepercayaan diri, dan belajar bersosialisasi. ${ }^{32}$ Nilai tersebut didapatkan dalam kegiatan perkemahan yang selalu diselenggarakan oleh pihak MI AlHidayah ketika liburan akhir tahun atau tahun ajaran baru. Kegiatan ini merupakan implementasi dari model blok yang diinternalisasikan melalui berbagai kegiatan seperti perlombaan, baris berbaris, jelajah, simpul, kepemimpinan, dan lain-lain.

Model aktualisasi yaitu kegiatan kepramukan yang diselenggarakan oleh pihak MI Al-Hidayah secara terjadwal pada tiap minggu yang diadakan setiap hari Sabtu dalam kurun waktu kurang lebih 120 menit. Dalam implementasi model ini, peserta didik berkebutuhan khusus diwajibkan mengikuti kegiatan sebagaimana yang sudah dijadwalkan oleh Pembina pramuka, namun dalam pelaksanaanya peserta didik yang mengalami hambatan untuk beraktivitas sebagaimana anak reguler, maka Pembina memodifikasi kegiatan pramuka. Seperti halnya, bagi anak yang mengalami hambatan untuk mengikuti tali temali, maka pembina menganjurkan peserta didik tersebut untuk melakukan kegiatan lainnya seperti bermain peta atau kompas. Dalam model aktualisasi ini, peserta didik ditanamkan nilai kedisiplinan, tanggung jawab, kejujuran, kebersaman, cinta dan peduli lingkungan, giat belajar, taat beribadah dan akhlak terpuji lainnya yang merupakan perwujudan dari dwi satya dan dwi dharma. Model reguler adalah kegiatan kepramukaan yang dilakukan sukarela berbasis minat peserta didik yang dilaksanakan di Gugus depan dan penyelenggaraan kegiatan ini diatur oleh Gugus Depan.

32. Abdul Qadimul Azal. Batuk Puter: Swabatik untuk Penguatan Karakter.Fikrotuna: Jurnal Pendidikan dan Manajemen Islam Volume. 10, Nomor. 02, Desember 2019, http://ejournal.kopertais4.or.id/madura/index.php/fikrotuna/article/view/3787, $\quad$ (Accessed September 18, 2020). 


\section{PENUTUP}

Madrasah Ibtidaiyah Al-Hidayah Margorejo merupakan salah satu madrasah yang sedang melakukan pengembangan untuk menjadi madrasah inklusi di Surabaya. Ketertarikan pihak madrasah Al-Hidayah untuk mengembangkan madrasahnya menjadi salah satu madrasah inklusi disebabkan keberadaan peserta didik di MI Al-Hidayah terdiri dari dua golongan yaitu peserta didik reguler dan peserta didik berkebutuhan khusus. Dengan kondisi perserta didik yang sedemikian rupa, maka pihak madrasah wajib memberikan pelayanan pendidikan yang sesuai dengan kebutuhan peserta didik, khususnya peserta didik yang berkebutuhan khusus. Salah satu bentuk pelayanan yang sesuai dengan karakteristik peserta didik adalah desain penguatan pendidikan karakter melalui kegiatan kepramukaan yang juga mengakomoodasi kebutuhan peserta didik berkebutuhan khusus. Adapun desain PPK melelui kepramukaan dilakukan dengan tiga model yaitu model blok, aktualisasi dan model reguler. Ketiga model tersebut dalam pelaksaanaanya disesuaikan dengan keberadaaan dan kemampuan peserta didik yang memerlukan modifikasi jika diterapkan pada peserta didik ABK. Adapun nilai-nilai karakter dikembangkan dengan merujuk nilai yang terkandung pada dwi satya dan dwi dharma. 


\section{Daftar Pustaka}

Atmaja, Jati Rinakri. Pendidikan dan Bimbingan Anak Berkebutuhan Khusus, (Bandung: PT Remaja Rosdakarya, 2019), Cet. 2.

Azal, Abdul Qadimul Batuk Puter: Swabatik untuk Penguatan Karakter.Fikrotuna: Jurnal Pendidikan dan Manajemen Islam Volume. 10, Nomor. 02, Desember 2019, http://ejournal.kopertais4.or.id/madura/index.php/fikrotuna/article/vie w/3787, (Accessed September 18, 2020).

Buli-Holmberg, Jorun dan Sujathamalini Jeyaprathaban.Effective Practice in Inclusive and Special Needs Education. International Journal of Special Education Vol 31, No: 1, 2016, https://scinapse.io/papers/2549013895, (Accessed September 18, 2020).

Erliani, Sa'adah. Peran Gerakan Pramuka Untuk Membentuk Karakter Kepedulian Sosial dan Kemandirian (Studi Kasus di SDIT Ukhwah dan MIS An-Nuriyyah 2 Banjarmasin), Jurnal Madrasah Ibtidaiyah Muallimuna Vol. 2 No. 1 Oktober 2016, https://jurnal.uinantasari.ac.id/index.php/adzka/article/view/2020, (accessed August 7, 2020).

Fajri, Em Zul, dan Ratu Aprillia, Kamus Lengkap Bahasa Indonesia. Jakarta: Difa Publisher.

Hartati, Siti. Pembinaan Karakter Siswa Melalui Kegiatan Kepramukaan Di SMP Negeri 5 Terbanggi Besar Lampung Tengah. Lampung: Fakultas Tarbiyah dan Keguruan Universitas Islam Negeri Raden Intan Lampung, 2018.

Hendarman, dkk, Konsep dan Pedoman Penguatan Pendidikan Karakter Tingkat Sekolah Dasar dan Sekolah Menengah Pertama, Jakarta: Kementerian Pendidikan dan Kebudayaan Republik Indonesia.

Indah Ratnawati dkk, Manajemen Pendidikan Karakter Peserta Didik Melalui Kegiatan ekstrakulikuler Pramuka, JAMP: Jurnal Administrasi dan Manajemen Pendidikan, Volume 1, Nomor 3 September 2018, http://journal2.um.ac.id/index.php/jamp/article/view/3690 (accessed August 20, 2020).

Kementrian Pendidikan Nasional Badan Penelitian dan Pengembangan Pusat Kurikulum, Pengembangan Pen.didikan Budaya dan Karakter Bangsa, Jakarta: 2010. 
Khoiriyah;, Anizar Ahmad ;,Dewi Fitriani, Model Pengembangan Kecakapan Berbahasa Anak Yang Terlambat Berbicara (Speech Delay), Jurnal Ilmiah Mahasiswa Pendidikan Anak Usia Dini, 1 (1), Agustus 2016. http://garuda.ristekbrin.go.id/documents/detail/446375, (accessed September 2, 2020).

Kusumawardani, Mei. Implementasi Nilai-Nilai Pendidikan Karakter Di Sekolah Menengah Kejuruan Negeri 4 Yogyakarta, Skripsi Program Studi pendidikan Teknik Boga Fakultas Teknik universitas Negeri Yogyakarta,2013.

Lampiran Peraturan Menteri Pendidikan dan Kebudayaan Republik Indonesia Nomor 64 Tahun 2014, Pedoman Pendidikan Kepramukaan Sebagai Kegiatan Ekstrakulikuler Wajib Pada Pendidikan Dasar dan Pendidikan Menengah.

Lubis, Rahmat Rifai. Historitas dan Dinamika Pendidikan Karakter di Indonesia, (jurnal An-Nahdhah, Vol.1 No. 2, Agustus-Januari 2019), https://www.researchgate.net/publication/338570297_HISTORISITA S_DAN_DINAMIKA_PENDIDIKAN_KARAKTER_DI_INDONESI $\underline{\text { A, }}$ (accessed August 20, 2020).

Marzuki; Lisa Hapsari, Pembentukan Karakter Siswa Melalui Kegiatan Kepramukaan Di MAN 1 Yogyakarta, Jurnal Pendidikan Karakter Tahun V, Nomor 2, Oktober 2015, https://journal.uny.ac.id/index.php/jpka/article/view/8619, (accessed August 6, 2020).

Maunah, Binti. Implementasi Pendidikan Karakter Dalam PembentukanKepribadian Holistik Siswa, Jurnal Pendidikan Karakter Tahun V , Nomor 1 April 2015, https://journal.uny.ac.id/index.php/jpka/article/view/8615, , (accessed August 20, 2020).

Megawangi, Ratna. Pendidikan Karakter: Solusi Yang Tepat Untuk Membangun Bangsa. Jakarta: Indonesia Heritage Foundation, 2004.

Mukaffa, Zumrotul. Pengembangan Model Madrasah Inklusif (Studi Atas Kesiapan dan Model Pengembangan Kurikulum Madrasah Inklusif MI Al-Hidayah Margorejo Surabaya), Edukasia,'Jurnal Penelitian Pendidikan Islam", Vol. 12, No. 1 Februari 2017, https://journal.iainkudus.ac.id/index.php/Edukasia/article/view/2051, (accessed August 20, 2020).

Mutmainah, Motivasi Belajar Siswa Slow Learner, Jurnal Bimbingan dan Konseling Ar-Rahman, Volume 3, No. 2, 2017, https://ojs.uniskabjm.ac.id/index.php/BKA/article/view/1038, (accesed August 6, 2020). 
McGrath, Robert E. What Is Character Education?: Development of a Prototype. Journal of Character Education Vol. 14, No. 2, 2018, https://eric.ed.gov/?id=EJ1199511 (accessed September 18, 2020).

Peraturan Menteri Pendidikan Nasional Nomor 70 Tahun 2009 Tentang Pendidikan Inklusif Bagi Peserta Didik Yang Memiliki Kelainan dan Memiliki Kecerdasan Dan/Atau Bakat istimewa, 2.

Poerwadarminta, Kamus Umum, 25; Dewan Redaksi Ensiklopedi Islam, Ensiklopedi Islam I Jakarta: PT. Ichtiar Baru Van Hoeve, 1994.

Rofiah, Nurul Hidayati. Penerapan Metode Pembelajaran Peserta Didik Slow Learner, Naturalistic: Jurnal Kajian Penelitian Pendidikan dan $\begin{array}{lllll}\text { Pembelajaran } & \text { No. } & 2, & 1 & \text { Oktober }\end{array}$ https://journal.umtas.ac.id/index.php/naturalistic/article/view/108, (accessed September 18, 2020).

Smith, J. David. Inklusi Sekolah Ramah Untuk Semua. Bandung: Penerbit Nuansa, 2006.

Suprihatin, Penguatan pendidikan Karakter Melalui Revitalisasi Gerakan Pramuka (Studi Kasus kegiatan Kepramukaan Kelas VII SMP Negeri 1 Trucuk Kabupaten Klaten 2012/2013. Surakarta: Fakultas Keguruan dan Ilmu Pendidikan Universitas Muhammadiyah Surakarta, 2014.

Wehr, Hans. A Dictionary of Modern Written Arabic, ed. J. Milton Cowan. Beirut: Maktabah Lubnan, 1980. 